\title{
Crown beaked whale fossils from the Chepotsunai Formation (latest Miocene) of Tomamae Town, Hokkaido, Japan
}

\author{
Yoshihiro Tanaka, Mahito Watanabe, and Masaichi Kimura
}

\begin{abstract}
In the last decades, our knowledge of ziphiid evolution has increased dramatically. However, their periotic morphology is still poorly known. A fossil ziphiid (TTM-1) including the periotic, bulla, isolated polydont teeth and vertebrae from the Chepotsunai Formation (latest Miocene) of Tomamae Town, Hokkaido, Japan, is identified as a member of a clade with crown ziphiids of Bianucci et al. (2016) by having three periotic synapomorphies; a posteriorly wide posterior process, transversely thick anterior process, and laterally elongated lateral process. The specimen adds morphological information of the periotic. Among the Ziphiidae from the stem to crown, the periotic morphologies were changed to having a more robust anterior process, wider anterior bullar facet and posterior process. The crown Ziphiidae shares a feature; enlarged medial tubercle on the anterior process. Among the crown Ziphiidae, TTM-1 does not have a swollen medial tubercle not like Tasmacetus, Nazcacetus and others. This new morphological information might represent useful future phylogenetic comparisons.
\end{abstract}

Yoshihiro Tanaka. Osaka Museum of Natural History, Nagai Park 1-23, Higashi-Sumiyoshi-ku, Osaka, 5460034, Japan.tanaka@mus-nh.city.osaka.jp

Hokkaido University Museum, Kita 10, Nishi 8, Kita-ku, Sapporo, Hokkaido 060-0810 Japan, Numata

Fossil Museum, 2-7-49, Minami 1, Numata town, Hokkaido 078-2225 Japan

Mahito Watanabe. AIST, Geological Survey of Japan, Research Institute for Geology and Geoinformation, Central 7, 1-1-1 Higashi, Tsukuba, Ibaraki, 305-8567 Japan. mht.watanabe@aist.go.jp

Masaichi Kimura. Hokkaido University of Education, Numata Fossil Museum, 2-7-49, Minami 1, Numata town, Hokkaido 078-2225 Japan. mkimura1313@yahoo.co.jp

Keywords: Ziphiidae; Odontoceti; Messinian; Periotic; Petrosal

Submission: 5 June 2018. Acceptance: 9 May 2019.

Tanaka, Yoshihiro, Watanabe, Mahito, and Kimura, Masaichi. 2019. Crown beaked whale fossils from the Chepotsunai Formation (latest Miocene) of Tomamae Town, Hokkaido, Japan. Palaeontologia Electronica 22.2.31A 1-14. https://doi.org/10.26879/897 palaeo-electronica.org/content/2019/2544-ziphiid-from-japan 


\section{INTRODUCTION}

In the last decade, our knowledge of fossil beaked whales has increased dramatically (Bianucci et al., 2005; Lambert, 2005; Lambert and Louwye, 2006; Bianucci et al., 2007; Fuller and Godfrey, 2007; Lambert et al., 2009; Bianucci et al., 2010; Lambert et al., 2010; Bianucci et al., 2013; Buono and Cozzuol, 2013; Lambert et al., 2013; Lambert et al., 2015; Ichishima et al., 2016; Lambert and Louwye, 2016; Ramassamy, 2016; Miján et al., 2017; Gioncada et al., 2018). The beaked whale family Ziphiidae includes two groups, crown Ziphiidae and a clade comprising the extinct Messapicetus (Bianucci et al., 2016). Among the fossil ziphiids, preserved ear bones are rare compared to the numbers of reported skulls.

A fossil ziphiid including fragmentary skull, periotic, bulla, vertebrae and isolated teeth from the latest Miocene of Hokkaido, Japan, was originally reported by Kimura (1997) and was implied to have a close relationships with Tasmacetus based on having polydont dentition. Later, Kimura (2003) mentioned that the specimen and Tasmacetus differ in the shape of the cross section of the teeth as oval and conical, respectively. Ichishima (2005) stated that polydont dentition might be a plesiomorphy for the Ziphiidae.

Here, we re-describe the polydont fossil ziphiid from the latest Miocene of Japan and discuss periotic morphological changes among the family. The specimen allows description of the relatively rare periotic and tympanic bulla within the Ziphiidae.

\section{MATERIAL AND METHODS}

Morphological terms follow Mead and Fordyce (2009) for the earbones.

Abbreviations. MNHN SAS, Muséum National d'Histoire Naturelle, Paris, France; MSM, Museum Sønderjylland Naturhistorie og Palæontologi, Gram Lergrav, Denmark; MSNTUP, Museo di Storia Naturale dell'Università di Pisa; MUSM, Museo de Historia Natural, Universidad Nacional Mayor de San Marcos, Lima, Peru; OU, Geology Museum, University of Otago, Dunedin, New Zealand; SMAC, Sapporo City Museum Activity Center, Hokkaido, Japan; TTM, Tomamae Town Museum, Hokkaido, Japan.

Material. TTM-1, a fragmentary skull, left periotic and tympanic bulla, 16 isolated teeth and three vertebrae.

Locality. TTM-1 was found at an outcrop in Tomamae Town, Hokkaido, Japan, by Haruo Fukuoka in

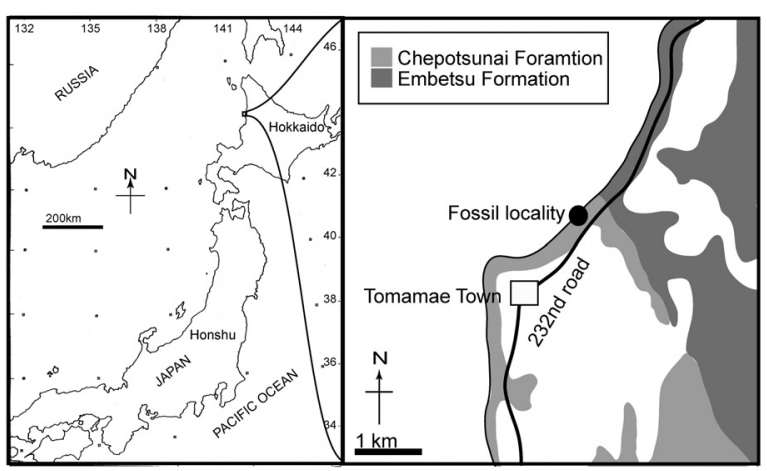

FIGURE 1. Maps showing the locality of TTM-1, Ziphiidae gen. et sp. indet. at Tomamae Town, Hokkaido, Japan.

August 1994 (Kimura, 1997). The site is about 800 $\mathrm{m}$ north from the city area (Figure 1): latitude $44^{\circ} 19^{\prime} 10^{\prime \prime} \mathrm{N}$, longitude $141^{\circ} 39^{\prime} 57^{\prime \prime} \mathrm{E}$.

Horizon and age. At the area, only two formations, the Embetsu and Chepotsunai Formations are exposed (Matsuno et al., 1962). The Embetsu Formation is diatomaceous mudstone and is exposed about $600 \mathrm{~m}$ northern coast from the TTM-1 locality. From the Embetsu Formation and at this locality, two fossil porpoises, Haborophocoena toyoshimai, H. minutus and Haborodelphis japonicus were reported (Ichishima and Kimura, 2009, 2013; Ichishima et al., 2018). The Chepotsunai Formation underlays the Embetsu Formation and is taffaceous sandstone with lignite. The matrix of TTM-1 is light gray calcareous sandstone.

The original horizon of TTM-1 is the Chepotsunai Formation as Kimura (1997) mentioned. Regarding Kimura (1997), the locality had about $8 \mathrm{~m}$ thickness of massive sand stone. The fossil was found from $2 \mathrm{~m}$ height at the outcrop. Upper to the horizon of the fossil, $6 \mathrm{~m}$ thickness of unconformity sandy mud stone sediments laid. The ear bones and teeth were deposited around the skull in about $60 \mathrm{~cm}$ cube. Lithology of the matrix from the skull is light gray fine sand but is not nodule. The matrices of TTM-1 on teeth show small dark green grains, which are probably glauconite. The diatom assemblage of TTM-1 (see Table 1) is assigned as NPD 7Ba (6.5-5.6 Ma; the latest Miocene, Messinian) of Yanagisawa and Akiba (1998), based on the occurrence of Neodenticula kamtschatica and absence of Neodenticula koizumii and Shionodiscus oestrupi. The assignment is supported by the presence of Thalassiosira temperei and absence of Rouxia californica. 
TABLE 1. Occurrence of diatom fossils in TTM-1. "+" indicates the taxon that occurs as small fragment or that found during the observation after count of one hundred diatom valves.

\begin{tabular}{lc}
\hline & TTM-1 \\
\hline Cocconeis spp. & + \\
Coscinodiscus marginatus Ehrenberg & 1 \\
Delphineis surirella (Ehrenberg) G. W. Andrews & + \\
D. simonsenii Yanagisawa et Akiba & + \\
Neodenticula kamtschatica (Zabelina) Akiba et & 8 \\
Yanagisawa & \\
Nitzschia grunnowi Hasle & + \\
N. rolandii Schrader emend. Koizumi & 48 \\
Paralia sulcata (Ehrenberg) Cleve & 1 \\
Rhizosolenia styliformis Brightwell & 2 \\
Thalassionema nitzschioides (Grunow) H. et M. & 26 \\
Peragallo & \\
Thalassiosira antiqua (Grunow) Cleve-Euler & + \\
T. jacksonii Koizumi et Barron in Koizumi & 2 \\
T. marujamica Sheshukova-Poretzkaya & 2 \\
T. nidulus (Tempère et Brun) Jousé & 1 \\
T. temperei (Brun) Akiba et Yanagisawa & 1 \\
T. spp. & 8 \\
Total & 100 \\
\hline &
\end{tabular}

\section{SYSTEMATIC PALEONTOLOGY}

Order CETACEA Brisson, 1762

Unranked taxon NEOCETI Fordyce and de

Muizon, 2001

Suborder ODONTOCETI Flower, 1867

Family ZIPHIIDAE Gray, 1850

Diagnosis. TTM-1 can be identified as a ziphiid, based on the presence of a poorly individualized dorsal keel on the posterior process of the periotic as character 41 in Bianucci et al. (2016).

Gen. et sp. indet

(Figures 2-8 and Tables 2, 3)

Diagnosis. TTM-1 can be identified as a member of the crown Ziphiidae of Bianucci et al. (2016) by three periotic synapomorphies, such as having a posteriorly widened posterior process (character 20 in Bianucci et al. (2016)); transversely thick anterior process (character 21 in the study); and laterally elongated lateral tuberosity (character 40 in the study). Some bulla characters were used in Bianucci et al. (2016), but none of them are preserved on the bulla of TTM-1.

Among the fossil ziphiids, preserved ear bones are rare compared to skulls. The periotic of TTM-1 is compared to the ones of six reported ziphiids, a late Miocene to early Pliocene Ninoziphius platyrostris, MNHN SAS 941 from Peru (Lambert et al., 2013); a late Miocene Messapicetus gregarius, MUSM 1438 from Peru

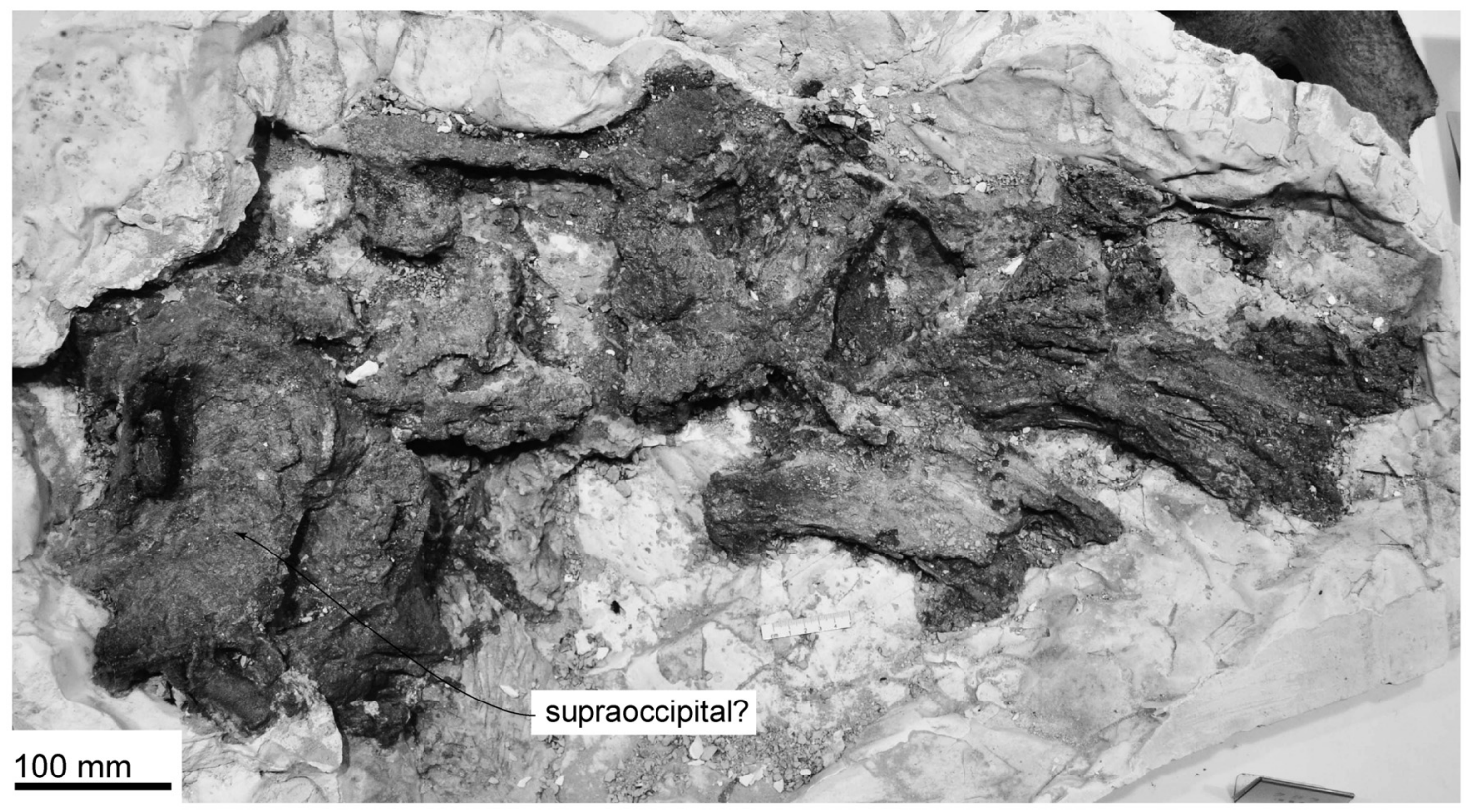

FIGURE 2. Fragmentary skull of TTM-1, Ziphiidae gen. et sp. indet. in dorsal view. 

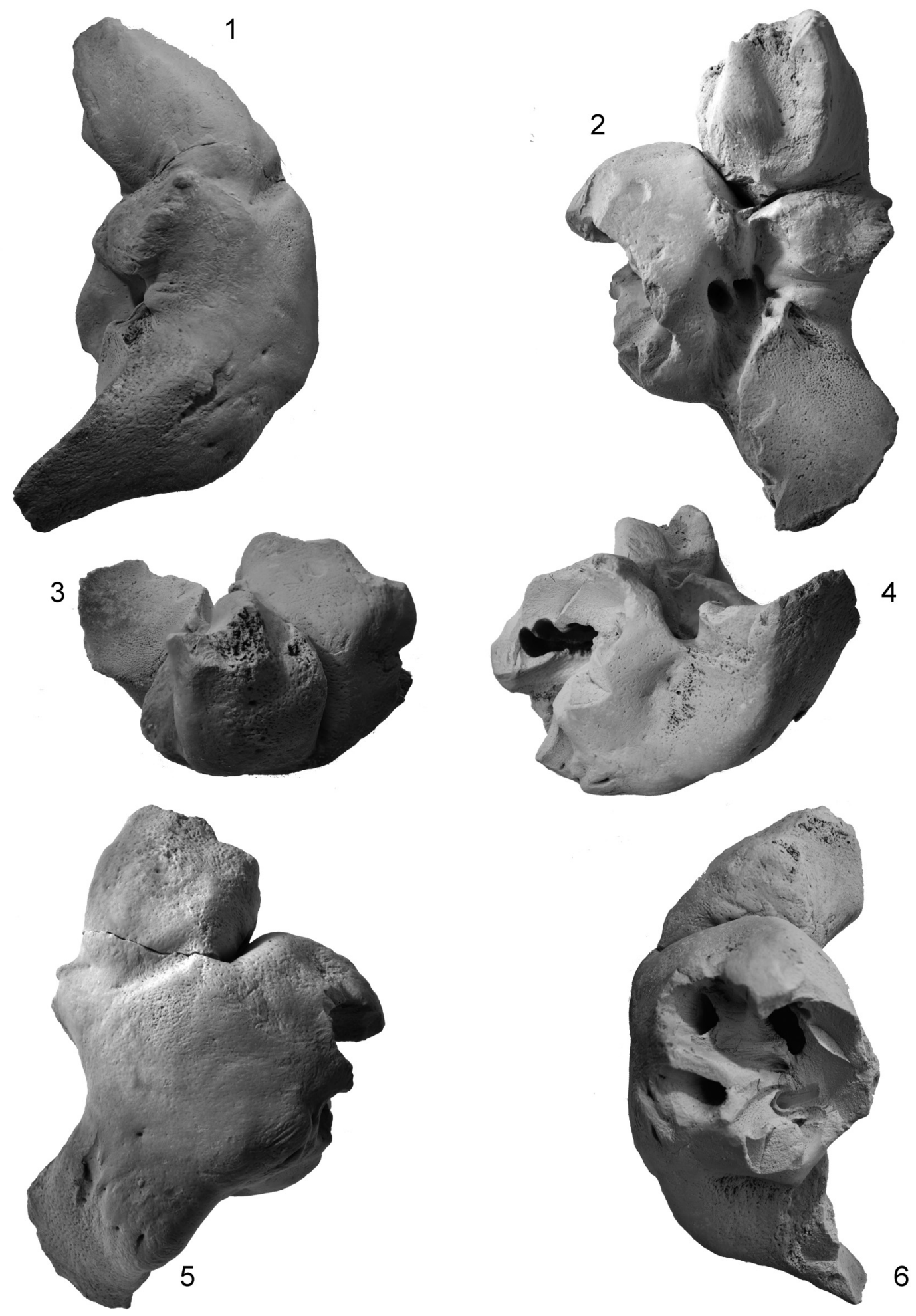

FIGURE 3. 1-6, Left periotic of TTM-1, Ziphiidae gen. et sp. indet., lateral (1), ventral (2), anterior (3), posterior (4), dorsal (5), medial (6). 


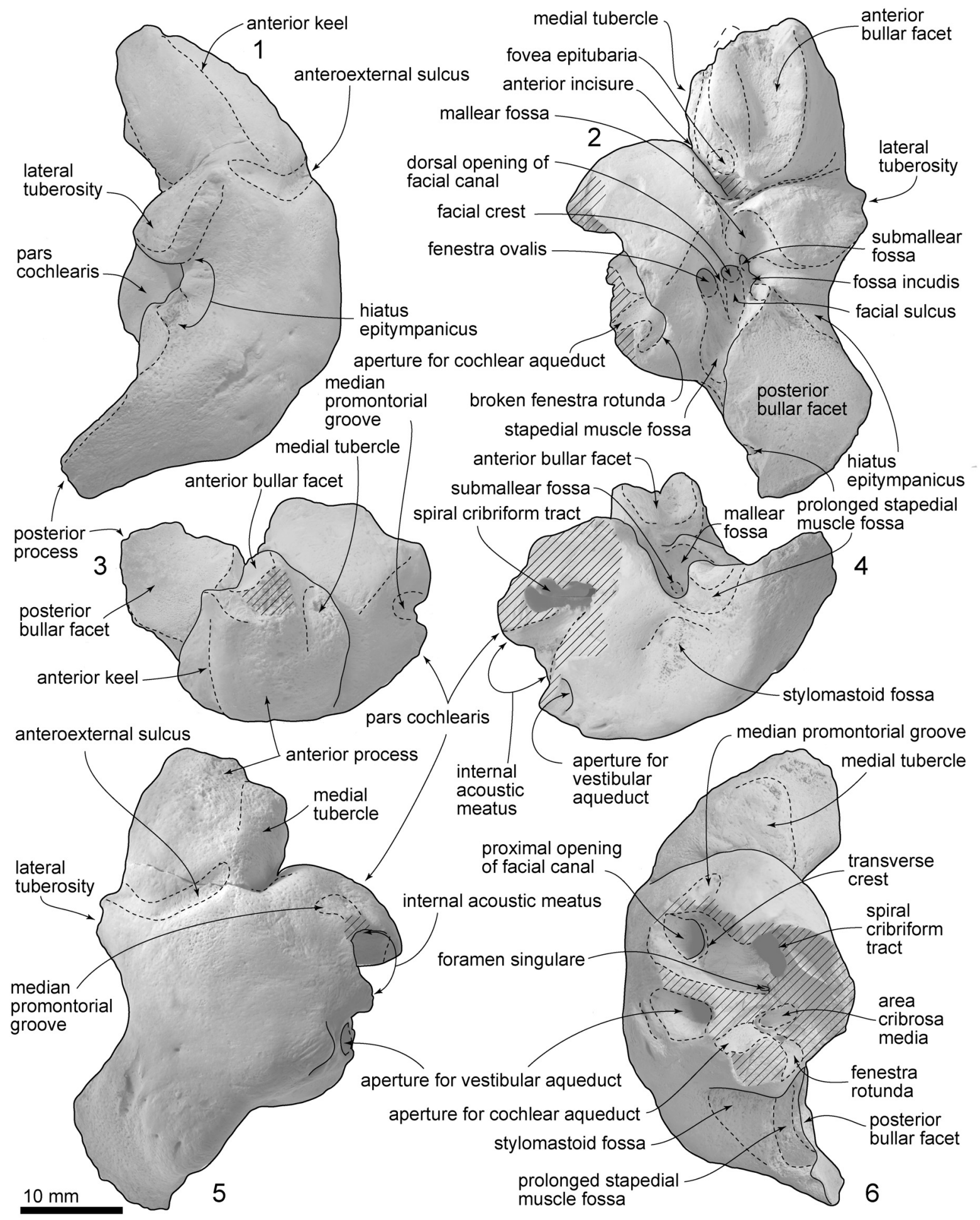

FIGURE 4. 1-6, Key features of the left periotic of TTM-1, Ziphiidae gen. et sp. indet., lateral (1), ventral (2), anterior (3), posterior (4), dorsal (5), medial (6). 


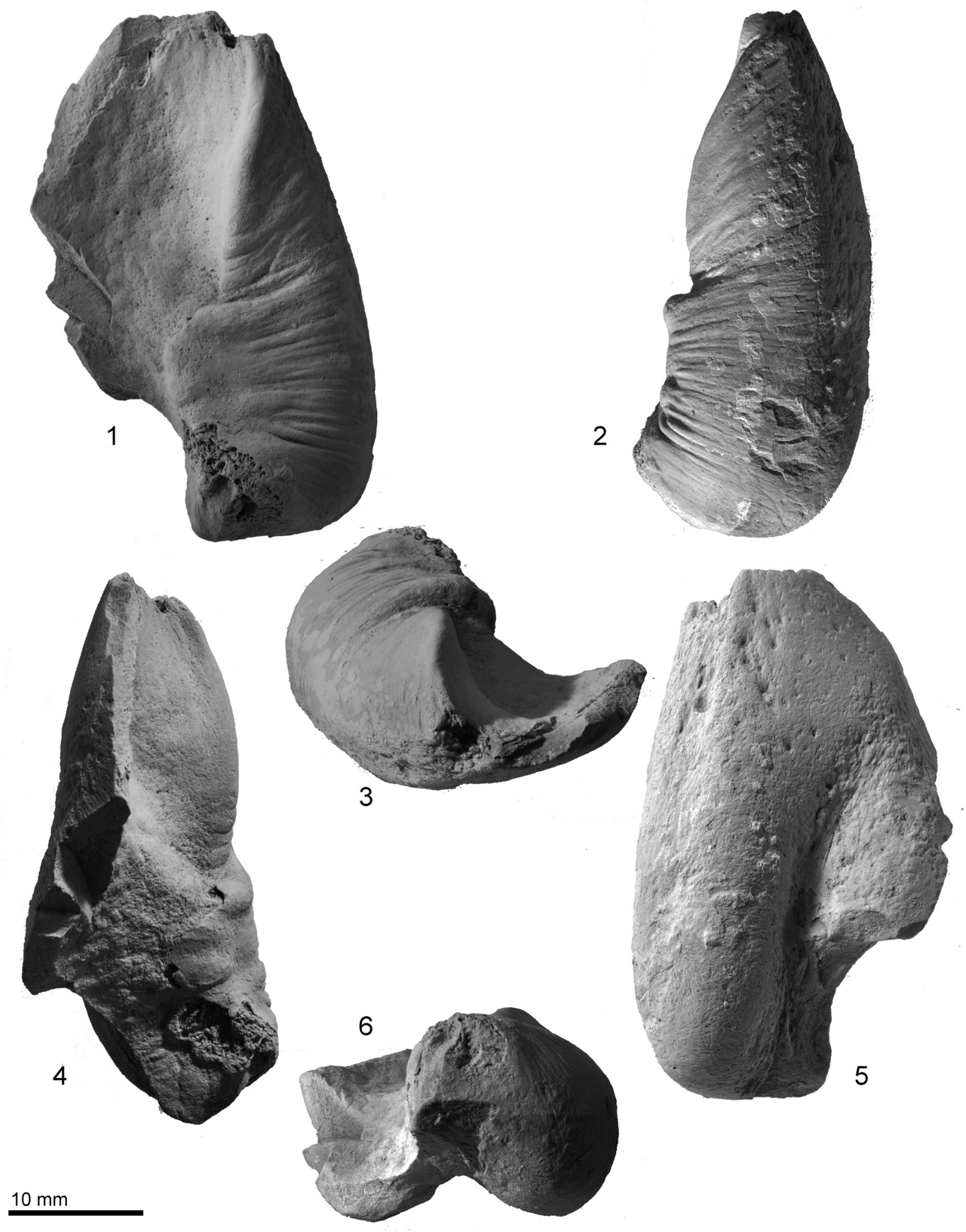

FIGURE 5. 1-6, Left tympanic bulla of TTM-1, Ziphiidae gen. et sp. indet. dorsal (1), medial (2), anterior (3), lateral (4), ventral (5), posterior (6). 


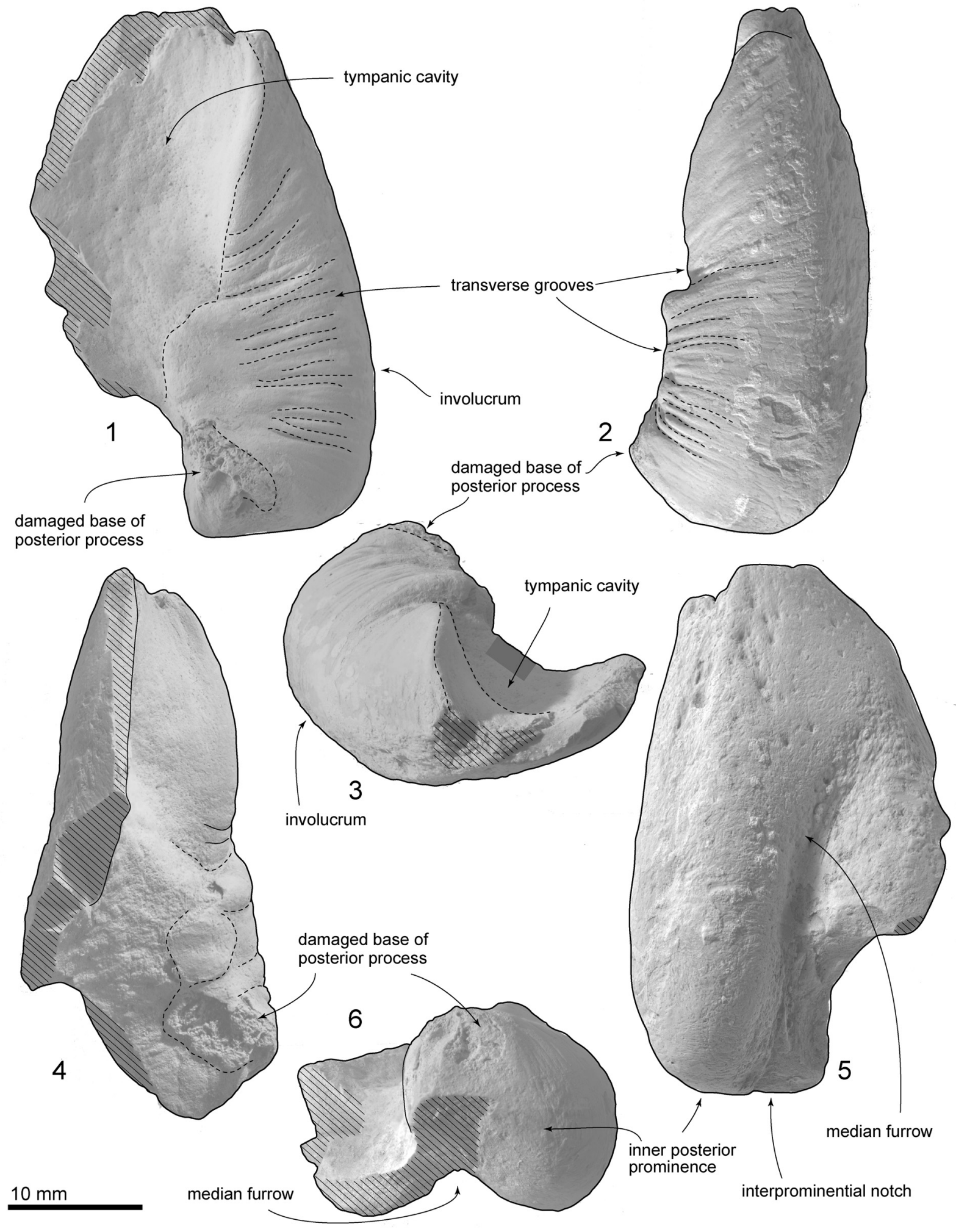

FIGURE 6. 1-6, Key features of the left tympanic bulla of TTM-1, Ziphiidae gen. et sp. indet. dorsal (1), medial (2), anterior (3), lateral (4), ventral (5), posterior (6). 

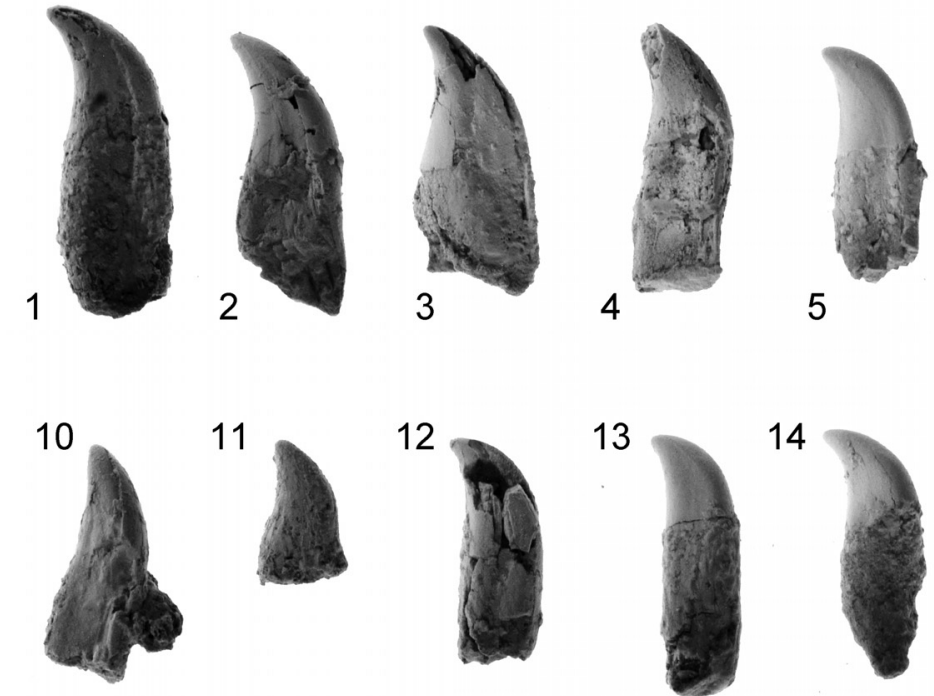

12

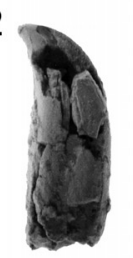

13
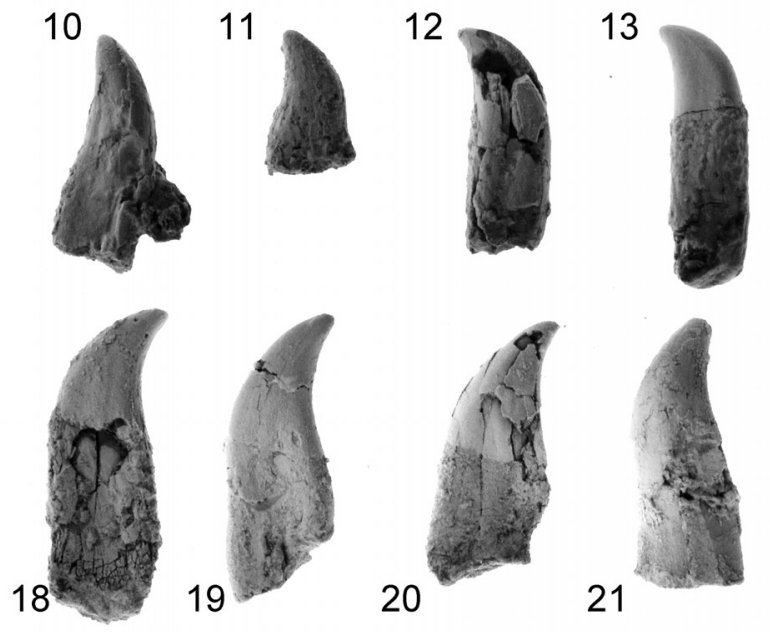

14
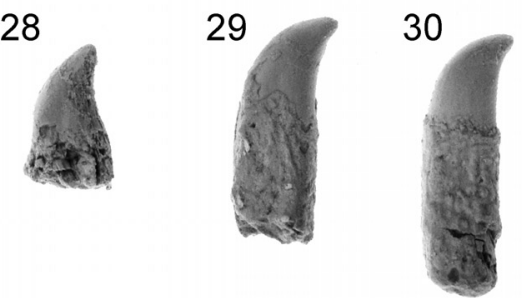

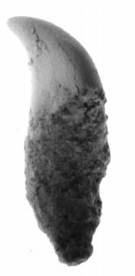

15
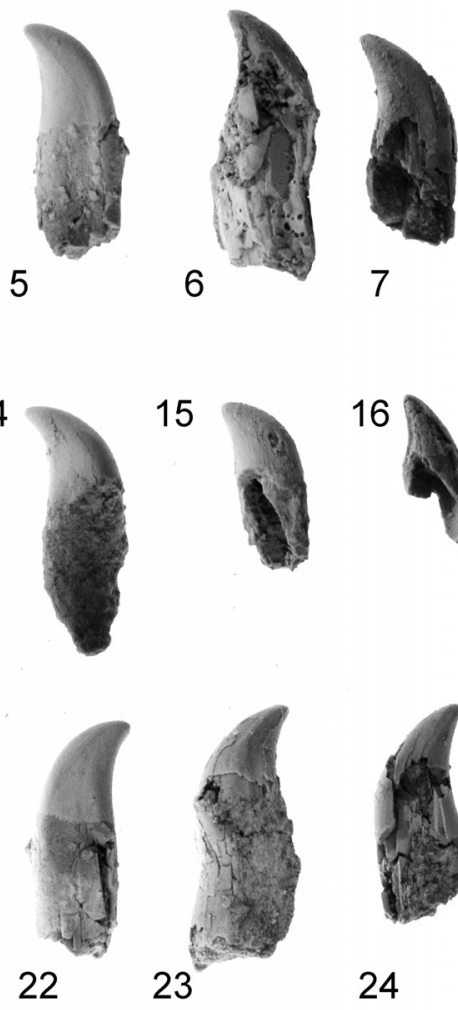

7

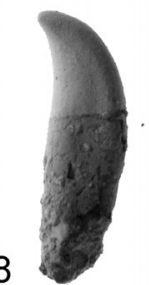

16

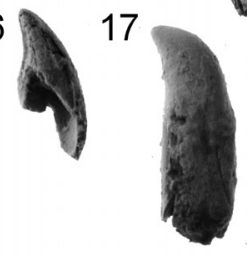

9
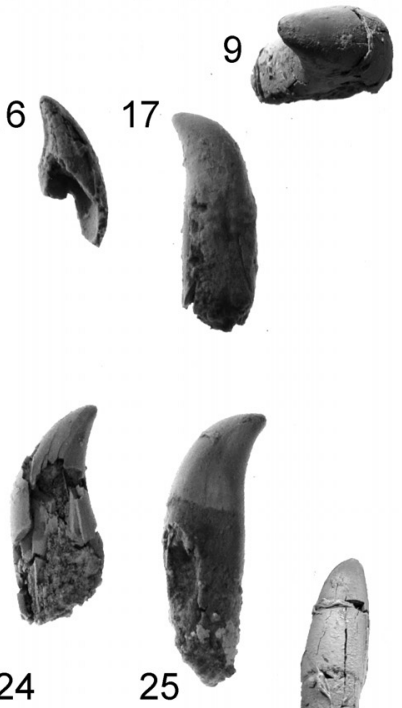

26

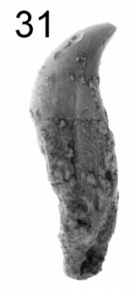

33

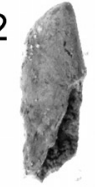

$50 \mathrm{~mm}$

FIGURE 7. 1-34, Teeth of TTM-1, Ziphiidae gen. et sp. indet., anterior or posterior view (1-8 and 10-17), other side of view of each teeth (18-25 and 27-34), apical view of tooth number 2 (8), lateral view of tooth number 2 (26).

(Bianucci et al., 2010); a late Miocene Dagonodum mojnum, MSM1001x from Denmark (Ramassamy, 2016); a middle Miocene Nazcacetus urbinai, MUSM 949 from Peru (Lambert et al., 2009); a late Early to Middle Miocene ziphiid, gen. et sp. indet. MSNTUP I13991 from Ecuador (Bianucci et al., 2005), and a late Miocene ziphiid, gen et sp. indet., MUSM3237 from Peru (Bianucci et al., 2016). We also compared with extant ziphiids using photos from Kasuya (1973), and actual specimens (Ziphius cavirostris, OU 22724; Tasmacetus shepherdi, OU no number; Mesoplodon grayi, OU no number; Mesoplodon stejnegeri, SMAC 3229).
The periotics of TTM-1+ Nazcacetus + extant ziphiids are differ from the periotics of Messapicetus + Ninoziphius by having a robust anterior process, wider anterior bullar facet, wider posterior process and an enlarged medial tubercle on the medial surface of the anterior process. But, comparison between the periotics of TTM-1 + Nazcacetus and (vs.) extant ziphiids, those of the extant ziphiids show more robust anterior process, wider anterior bullar facet and wider posterior process. The periotic of TTM-1 differs from those of the extant ziphiids and Nazcacetus by having a not swollen lateral side of the anterior process. 

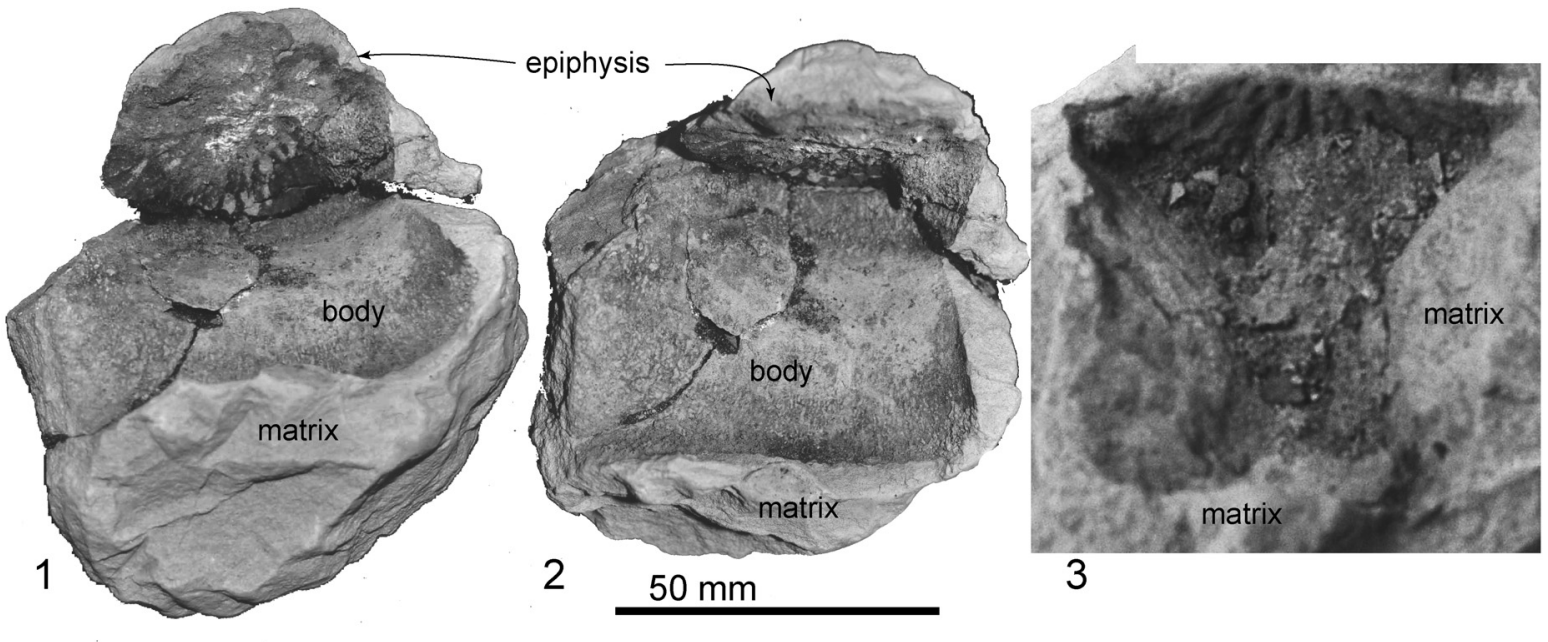

FIGURE 8. 1-3, The vertebrae of TTM-1, Ziphiidae gen. et sp. indet., vertebra number A anteroposterior view (1), vertebra number A dorsoventral view (2), vertebra number B in dorsoventral view (3).

\section{GENERAL DESCRIPTION}

Ontogeny. All three preserved vertebrae show unfused epiphyses to the bodies. Based on these observations, TTM-1 is a juvenile to subadult.

Skull. A flat, squashed and fragmentary huge bone (Figure 2) does not show clear morphological information. A side of the skull is stuck by plaster jacket to protect the specimen. There is a huge flat area on the left side of Figure 2, which might be the supraoccipital. On the right side, there is a bone with thin layers, which might be a part of the rostrum. If this identification was correct, the skull is about $86+\mathrm{cm}$ long and $30+\mathrm{cm}$ wide.

Periotic. The periotic (Figures 3, 4 and Table 2) has a robust anterior process, a long posterior process and a dorsoventrally high, medially broken

TABLE 2. Measurements in mm of TTM-1: periotic and tympanic bulla. Measurements are rounded to the nearest 0.5 $\mathrm{mm}$.

\begin{tabular}{lc}
\hline Periotic & 47.5 \\
maximum anteroposterior length from anterior apex of anterior process to apex of posterior process & 48.0 \\
maximum anteroposterior length parallel to dorsal margin & 17.5 \\
maximum dorsoventral depth anterior process perpendicular to axis of periotic & 17.0 \\
length of anterior process from anterior apex to level of posterior of mallear fossa & 11.0 \\
length of anterior process from anterior apex of anterior process to level of anterior of pars & 20.5 \\
cochlearis in notch immediately lateral to fine ridge & \\
length facet on posterior process point to point & 14.0 \\
ventral opening of facial canal anteroposterior diameter & 26.0 \\
maximum width of anterior process at base & $16.5+$ \\
approximate anteroposterior length of pars cochlearis & $30.5+$ \\
approximate transverse width of pars cochlearis from internal edge to fenestra ovalis & 20.5 \\
transverse width of periotic, internal face of pars cochlearis to apex of lateral tuberosity & 20.5 \\
length of posterior process of periotic & \\
length of posterior process parallel to posterior profile/ steeply acute to long axis of body & \\
Tympanic bulla & $40.0+$ \\
standard length anterior apex to apex of outer posterior prominence & $38.0+$ \\
length anterior apex to apex of inner posterior prominence & 14.5 \\
dorsoventral depth of involucrum immediately in front of posterior pedicle & \\
\hline
\end{tabular}


TABLE 3. Measurements in $\mathrm{mm}$ of TTM-1: teeth. Teeth numbers follow figure 7 . Measurements are rounded to the nearest $0.5 \mathrm{~mm}$. The asterisk $\left(^{*}\right)$ means squashed.

\begin{tabular}{|c|c|c|c|}
\hline A & & $\mathrm{J}$ & \\
\hline Total length & 26.8 & Total length & 19.6 \\
\hline Crown length & 10.8 & Crown length & 12.0 \\
\hline Mediolateral diameter & $5.1^{*}$ & Mediolateral diameter & $4.1^{*}$ \\
\hline Anteroposterior diameter & 10.1 & Anteroposterior diameter & 8.0 \\
\hline$B, I$ & & $\mathrm{~K}$ & \\
\hline Total length & $25.2+$ & Total length & $12.6+$ \\
\hline Crown length & 12.0 & Crown length & 7.9 \\
\hline Mediolateral diameter & $4.8^{*}$ & Mediolateral diameter & $4.6^{*}$ \\
\hline Anteroposterior diameter & 8.5 & Anteroposterior diameter & 7.9 \\
\hline C & & L & \\
\hline Total length & $23.3+$ & Total length & $19.7+$ \\
\hline Crown length & 12.7 & Crown length & 9.7 \\
\hline Mediolateral diameter & $4.1^{*}$ & Mediolateral diameter & $5.2^{*}$ \\
\hline Anteroposterior diameter & 10.9 & Anteroposterior diameter & 7.2 \\
\hline D & & M & \\
\hline Total length & $23.4+$ & Total length & $22.4+$ \\
\hline Crown length & $8.5^{+}$ & Crown length & 8.4 \\
\hline Mediolateral diameter & $5.1+$ & Mediolateral diameter & 6.6 \\
\hline Anteroposterior diameter & 8.0 & Anteroposterior diameter & 5.3 \\
\hline$E$ & & $\mathrm{~N}$ & \\
\hline Total length & $20.5+$ & Total length & $21.8+$ \\
\hline Crown length & 9.0 & Crown length & 8.5 \\
\hline Mediolateral diameter & 7.0 & Mediolateral diameter & 5.4 \\
\hline Anteroposterior diameter & 5.0 & Anteroposterior diameter & 6.5 \\
\hline $\mathrm{F}$ & & $\mathrm{O}$ & \\
\hline Total length & $22.2+$ & Total length & $15.4+$ \\
\hline Crown length & 8.9 & Crown length & 8.7 \\
\hline Mediolateral diameter & 5.6 & Mediolateral diameter & 5.9 \\
\hline Anteroposterior diameter & 7.9 & Anteroposterior diameter & $6.0+$ \\
\hline G & & $\mathrm{P}$ & \\
\hline Total length & $18.8+$ & Total length & $13.6+$ \\
\hline Crown length & 11.0 & Crown length & $13.6+$ \\
\hline Mediolateral diameter & $4.7^{*}$ & Mediolateral diameter & $6.0+$ \\
\hline Anteroposterior diameter & 7.3 & Anteroposterior diameter & $4.3+$ \\
\hline $\mathrm{H}$ & & Q & \\
\hline Total length & $23.7+$ & Total length & $19.0+$ \\
\hline Crown length & 9.6 & Crown length & 8.1 \\
\hline Mediolateral diameter & 5.0 & Mediolateral diameter & 6.0 \\
\hline Anteroposterior diameter & 6.9 & Anteroposterior diameter & 5.6 \\
\hline
\end{tabular}


pars cochlearis, which is anteroposteriorly longer than the anterior process. Both the anterior and posterior processes are straight, but are strongly bent ventrally compared to the axis of the body of the periotic.

The anterior process is robust and weakly bent ventrally. The anterior process has an anteroposteriorly long excavated anterior bullar facet. There is a laterally swollen medial tubercle of the anterior process (Tanaka and Fordyce, 2016), which contacts with the pars cochlearis and forms the anterior incisure. Slightly lateral to the anterior incisure on the anterior process, there is a shallow fovea epitubaria (about $1.5 \mathrm{~mm}$ diameter). Dorsally, a deep anteroexternal sulcus runs from just anterior to the lateral tuberosity to the medial tubercle. The anterior keel runs dorsolaterally.

The pars cochlearis is anteroposteriorly longer than the anterior process, and is broken laterally. The anteromedial surface of the pars cochlearis has a weak depression, which is a part of the median promontorial groove. The broken internal acoustic meatus reveals the spiral cribriform tract anteriorly and area cribrosa media posteriorly. The proximal opening of the facial canal is large and possesses anteroposteriorly long elliptical shape (3.5 and $1.5 \mathrm{~mm}$ diameter). The foramen singulare is very tiny (about $0.1 \mathrm{~mm}$ diameter) and located very deep at ventral to the transverse crest. The aperture for cochlear aqueduct is large and circular (about $3.0 \mathrm{~mm}$ diameter). The preserved lateral margin of the fenestra rotunda implies that the size of the foramen is $3 \mathrm{~mm}$ diameter or slightly larger.

On the body of the periotic in ventral view, the mallear fossa is clear and mediolaterally wide elliptical shape $(4.3 \mathrm{~mm}$ long and $5.5 \mathrm{~mm}$ wide), but shallower than the condition of the modern ziphiids. The mallear fossa is anterolaterally restricted by a sigmoidal ridge, which continues to the lateral tuberosity.

The lateral tuberosity is well developed and separated from the anterior process. Between the mallear fossa and dorsal opening of the facial canal, there is a tiny deep submallear fossa (Tanaka and Fordyce, 2017). A deep and small fossa incudis is located posterior to the submallear fossa and anterior to the posterior process. The facial crest of the periotic separates an anteroposteriorly long elliptical fenestra ovalis (2.0 and 1.6 $\mathrm{mm}$ diameter) and a circular dorsal opening of the facial canal $(1.0 \mathrm{~mm}$ diameter). The facial sulcus runs from the dorsal opening of the facial canal, and connects to a shallow and wide stapedial mus- cle fossa medially. The dorsal surface of the body of the periotic is smooth and flat.

A fan-shaped posterior process is anteroposteriorly long and widens posteriorly. The posterior bullar facet is smooth, has raised medial and lateral ridges and an anteroposteriorly long depression between the ridges. The posteromedial part of the posterior process has a small notch, which is a part of the prolonged stapedial muscle fossa. The dorsal keel of the posterior process is weak.

Bulla. The left bulla (Figures 5, 6 and Table 2) preserves the involucrum, but its lateral part is broken. In the anterior portion of the involucrum, there is a distinctive transverse depression. The involucrum has many transverse deep grooves on the ventral and medial surfaces. The involucrum proportion can be separated at the midway as slender and anteriorly tapered anterior portion and thick and laterally swollen posterior portion. A broken base of the posterior process lies on the ventral surface of the posterior end of the involucrum. The posterior end of the involucrum is blunt rather than rounded. Ventrally, a deep and narrow median furrow runs anteroposteriorly. Medial to the median furrow, the inner posterior prominence weakly project posteriorly.

Teeth. TTM-1 is polydont and near-homodont (Figure 7, Table 3). Sixteen isolated single-rooted teeth are preserved. The original orientation of the teeth is determined based on preserved teeth of the fossil ziphiids such as Ninoziphius platyrostris and Chavinziphius maxillocristatus (Bianucci et al., 2010; Lambert et al., 2013; Bianucci et al., 2016). All the preserved teeth have conical to anteroposteriorly flattened crowns, which are buccolingually weakly curved (Figure 7.9). All the preserved teeth possess weakly pointed crowns with no apical wear. The teeth are hollow, thus some of the teeth are crashed buccolingually. All the preserved roots are apicobasally longer than their crowns.

Four larger teeth (Figure 7.1-4) are about 26$23 \mathrm{~mm}$ in total apicobasal length, with a crown height of $12-10 \mathrm{~mm}$. These teeth have a wide root. Based on the root shape and size, they are posterior teeth. Twelve smaller teeth (Figure 7.5-8 and $7.10-17)$ are $19 \mathrm{~mm}$ or smaller in total dimension. The crown heights are about $9-8 \mathrm{~mm}$. These smaller crowns have a weaker degree of curvature than the larger teeth. This is especially evident in the smallest teeth (Figure 7.12-17), which possess anteroposteriorly shorter roots, circular in cross sections.

Vertebrae. Only bodies of three vertebrae are preserved (Figure 8). They are slightly anteroposteriorly longer than the transverse width (Vertebra 


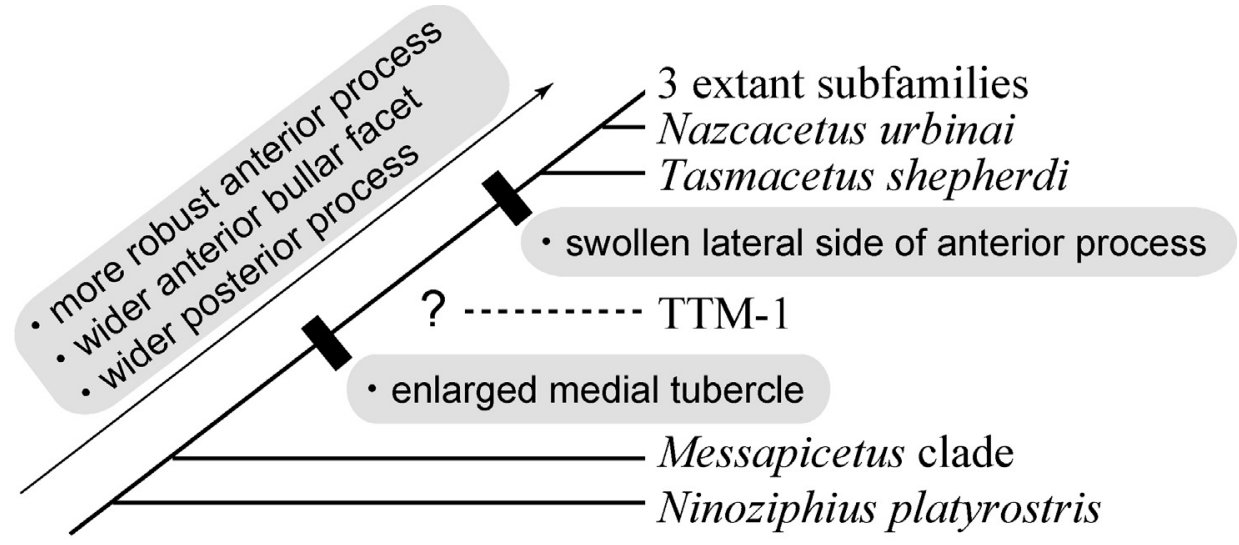

FIGURE 9. Morphological changes of the periotics among the Ziphiidae. The cladogram is modified from figure 13 of Bianucci et al. (2016).

number $A$ is $50 \mathrm{~mm}$ long, $60 \mathrm{~mm}$ wide. Vertebra number $B$ is $82 \mathrm{~mm}$ long, $75 \mathrm{~mm}$ wide). These preserved vertebrae possess unfused epiphyses.

\section{DISCUSSION}

\section{Periotic Morphology and Transition among the Ziphiidae}

As compared in the systematic paleontology section, among the Ziphiidae from the stem to crown, the periotic morphology seems to be changed to more robust anterior process, wider anterior bullar facet and posterior process (Figure 9). The crown Ziphiidae of Bianucci et al. (2016) including TTM-1 share a feature; enlarged medial tubercle on the anterior process. The periotics of Ninoziphius and Messapicetus clade also show the medial tubercle, but they do not contact with the pars cochlearis. The lateral side of the anterior process in ventral view might represent useful future phylogenetic comparisons. TTM-1 does not have a swollen lateral side of the anterior process, not like Tasmacetus, Nazcacetus and others.

\section{CONCLUSION}

TTM-1 from the Chepotsunai Formation (latest Miocene) of Tomamae Town, Hokkaido, Japan, (including the periotic, bulla, isolated teeth and vertebrae) is identified as a member of a clade with crown ziphiids of Bianucci et al. (2016) by three periotic synapomorphies, such as having a posteriorly widen posterior process, transversely thick anterior process and laterally elongated lateral pro- cess. TTM- 1 is polydont and its teeth are similar to those of Ziphirostrum marginatum of the extinct Messapicetus clade. TTM-1 adds periotic morphology among the Ziphiidae. From the stem to crown, the periotic morphologies seem to be changed to more robust anterior process, wider anterior bullar facet and posterior process. The crown Ziphiidae of Bianucci et al. (2016) including TTM-1 share a feature; enlarged medial tubercle on the anterior process. TTM-1 does not have a swollen lateral side of the anterior process, not like Tasmacetus, Nazcacetus and others. These features might be used for phylogenetic analysis. The proportions of the anterior process and posterior process of a baleen whale group, the Balaenopteridae are known as parts showing ontogenetic variation (Bisconti, 2001). Examined modern ziphiids in this study are not really known for their ontogenetic stages. However, a supposed not fully adult individual of Mesoplodon grayi (OU no number) with an opened mesorostral groove also shows robust anterior and posterior processes. More data, especially ontogenetic variation among the Ziphiidae periotics is required.

\section{ACKNOWLEDGMENTS}

We thank H. Fukuoka, who collected the specimen; Tomamae Educational Board for providing opportunities to study the specimen; H. Furusawa and M. Yamazaki (SMAC) for giving access to comparative materials. We also thank two anonymous reviewers for providing constructive comments on this manuscript. 


\section{REFERENCES}

Bianucci, G., Di Celma, C., Urbina, M., and Lambert, O. 2016. New beaked whales from the late Miocene of Peru and evidence for convergent evolution in stem and crown Ziphiidae (Cetacea, Odontoceti). PeerJ, 4:e2479. https://doi.org/10.7717/peerj.2479

Bianucci, G., Lambert, O., and Post, K. 2007. A high diversity in fossil beaked whales (Mammalia, Odontoceti, Ziphiidae) recovered by trawling from the sea floor off South Africa. Geodiversitas, 29(4):561-618.

Bianucci, G., Lambert, O., and Post, K. 2010. High concentration of long-snouted beaked whales (genus Messapicetus) from the Miocene of Peru. Palaeontology, 53(5):1077-1098. https:// doi.org/10.1111/j.1475-4983.2010.00995.x

Bianucci, G., Landini, W., Valleri, G., Ragaini, L., and Varola, A. 2005. First cetacean fossil records from Ecuador, collected from the Miocene of Esmeraldas Province. Rivista Italiana di Paleontologia e Stratigrafia, 111(2):345-350. https://doi.org/10.13130/2039-4942/6325

Bianucci, G., Miján, I., Lambert, O., Post, K., and Mateus, O. 2013. Bizarre fossil beaked whales (Odontoceti, Ziphiidae) fished from the Atlantic Ocean floor off the Iberian Peninsula. Geodiversitas, 35(1):105-153. https://doi.org/10.5252/g2013n1a6

Bisconti, M. 2001. Morphology and postnatal growth trajectory of rorqual petrosal. Italian Journal of Zoology, 68(2):87-93. https://doi.org/10.1080/11250000109356390

Brisson, A. 1762. Regnum Animale in Classes IX Distributum Sive Synopsis Methodica. Edito altero auctior. Theodorum Haak, Leiden.

Buono, M.R. and Cozzuol, M.A. 2013. A new beaked whale (Cetacea, Odontoceti) from the Late Miocene of Patagonia, Argentina. Journal of Vertebrate Paleontology, 33(4):986-997. https:// doi.org/10.1080/02724634.2013.752377

Flower, W.H. 1867. Description of the skeleton of Inia geoffrensis and the skull of Pontoporia blainvillii, with remarks on the systematic position of these animals in the Order Cetacea. Transactions of the Zoological Society of London, 6(3):87-116.

Fordyce, R.E. and de Muizon, C. 2001. Evolutionary history of whales: A review, p. 169-234. In Mazin, J.-M. and de Buffrenil, V. (eds.), Secondary Adaptation of Tetrapods to Life in Water. Pfeil, München, Germany.

Fuller, A.J. and Godfrey, S.J. 2007. A late Miocene ziphiid (Messapicetus sp.: Odontoceti: Cetacea) from the St. Marys Formation of Calvert Cliffs, Maryland. Journal of Vertebrate Paleontology, 27(2):535-540. https://doi.org/10.1671/02724634(2007)27[535:ALMZMS]2.0.CO;2

Galatius, A., Berta, A., Frandsen, M.S., and Goodall, R.N.P. 2011. Interspecific variation of ontogeny and skull shape among porpoises (Phocoenidae). Journal of Morphology, 272(2):136-148. https://doi.org/10.1002/jmor.10900

Gioncada, A., Petrini, R., Bosio, G., Gariboldi, K., Collareta, A., Malinverno, E., Bonaccorsi, E., Di Celma, C., Pasero, M., and Urbina, M. 2018. Insights into the diagenetic environment of fossil marine vertebrates of the Pisco Formation (late Miocene, Peru) from mineralogical and Sr-isotope data. Journal of South American Earth Sciences, 81:141-152. https://doi.org/ 10.1016/j.jsames.2017.11.014

Gray, J.E. 1850. Catalogue of the Specimens of Mammalia in the Collection of the British Museum. Part 1-Cetacea. British Museum, London.

Ichishima, H. 2005. A re-evaluation of some Japanese cetacean fossils. Memoir of the Fukui Prefectural Dinosaur Museum, 4:1-20.

Ichishima, H., Augustin, A.H., Toyofuku, T., and Kitazato, H. 2017. A new species of Africanacetus (Odontoceti: Ziphiidae) found on the deep ocean floor off the coast of Brazil. Deep Sea Research Part II: Topical Studies in Oceanography, 146:68-81. https://doi.org/ 10.1016/j.dsr2.2016.12.002

Ichishima, H., Furusawa, H., Tachibana, M., and Kimura, M. 2018. First monodontid cetacean (Odontoceti, Delphinoidea) from the early Pliocene of the north-western Pacific Ocean. Papers in Palaeontology, 5(2):1-20. https://doi.org/10.1002/spp2.1244

Ichishima, H. and Kimura, M. 2005. Haborophocoena toyoshimai, a new Early Pliocene porpoise (Cetacea; Phocoenidae) from Hokkaido, Japan. Journal of Vertebrate Paleontology, 25(3):655-664. https://doi.org/10.1671/0272-4634(2005)025[0655:HTANEP]2.0.CO;2 
Ichishima, H. and Kimura, M. 2009. A new species of Haborophocoena, an Early Pliocene phocoenid cetacean from Hokkaido, Japan. Marine Mammal Science, 25(4):855-874. https:// doi.org/10.1111/j.1748-7692.2009.00293.x

Ichishima, H. and Kimura, M. 2013. New material of Haborophocoena toyoshimai (Odontoceti: Phocoenidae) from the lower Pliocene Embetsu Formation of Hokkaido, Japan. Paleontological Research, 17(2):127-137. https://doi.org/10.2517/1342-8144-17.2.127

Kasuya, T. 1973. Systematic consideration of recent toothed whales based on the morphology of tympano-periotic bone. Scientific Reports of the Whales Research Institute, Tokyo, 25:1-103.

Kimura, M. 1997. Discovery of an Odontoceti from Tomamae Town, Hokkaido, Japan. Kyoudo to Kagaku, 110:19-22.

Kimura, M. 2003. Ancient Hokkaido-Pleasure of Visiting the Fossil Museums. The Hokkaido Shimbun Press, Hokkaido, 207 pp.

Kurihara, N. and Oda, S. 2009. Effects of size on the skull shape of the bottlenose dolphin (Tursiops truncatus). Mammal Study, 34(1):19-32. https://doi.org/10.3106/041.034.0104

Lambert, O. 2005. Systematics and phylogeny of the fossil beaked whales Ziphirostrum du Bus, 1868 and Choneziphius Duvernoy, 1851 (Mammalia, Cetacea, Odontoceti), from the Neogene of Antwerp (North of Belgium). Geodiversitas, 27(3):443-497.

Lambert, O., Bianucci, G., and Post, K. 2009. A new beaked whale (Odontoceti, Ziphiidae) from the Middle Miocene of Peru. Journal of Vertebrate Paleontology, 29(3):910-922. https:// doi.org/10.1671/039.029.0304

Lambert, O., Bianucci, G., and Post, K. 2010. Tusk-bearing beaked whales from the Miocene of Peru: sexual dimorphism in fossil ziphiids? Journal of Mammalogy, 91(1):19-26. https:// doi.org/10.1644/08-MAMM-A-388R1.1

Lambert, O., Collareta, A., Landini, W., Post, K., Ramassamy, B., Di Celma, C., Urbina, M., and Bianucci, G. 2015. No deep diving: evidence of predation on epipelagic fish for a stem beaked whale from the Late Miocene of Peru. Proceedings of the Royal Society B: Biological Sciences, 282(1815):1-8. https://doi.org/10.1098/rspb.2015.1530

Lambert, O. and Louwye, S. 2006. Archaeoziphius microglenoideus, a new primitive beaked whale (Mammalia, Cetacea, Odontoceti) from the Middle Miocene of Belgium. Journal of Vertebrate Paleontology, 26(1):182-191. https://doi.org/10.1671/02724634(2006)26[182:amanpb]2.0.co;2

Lambert, O. and Louwye, S. 2016. A new early Pliocene species of Mesoplodon: A calibration mark for the radiation of this species-rich beaked whale genus. Journal of Vertebrate Paleontology, 36(2):e1055754. https://doi.org/10.1080/02724634.2015.1055754

Lambert, O., Muizon, C., and Bianucci, G. 2013. The most basal beaked whale Ninoziphius platyrostris Muizon, 1983: Clues on the evolutionary history of the family Ziphiidae (Cetacea: Odontoceti). Zoological Journal of the Linnean Society, 167(4):569-598. https://doi.org/ 10.1111/zoj.12018

Matsuno, H., Tanaka, K., Yamaguchi, S., and Hata, M. 1962. Geology of the Haboro District, 1:200000, Wakkanai 18. Geological Survey of Japan, Tokyo.

Mead, J.G. and Fordyce, R.E. 2009. The therian skull: a lexicon with emphasis on the odontocetes. Smithsonian Contributions to Zoology, 627:1-248. https://doi.org/10.5479/ si.00810282.627

Miján, I., Louwye, S., and Lambert, O. 2017. A new Beneziphius beaked whale from the ocean floor off Galicia, Spain and biostratigraphic reassessment of the type species. Acta Paleontologica Polonica, 62(1):211-220. https://doi.org/10.4202/app.00309.2016

Ramassamy, B. 2016. Description of a new long-snouted beaked whale from the Late Miocene of Denmark: Evolution of suction feeding and sexual dimorphism in the Ziphiidae (Cetacea: Odontoceti). Zoological Journal of the Linnean Society, 178(2):381-409. https://doi.org/ 10.1111/zoj.12418

Tanaka, Y. and Fordyce, R.E. 2016. Papahu-like fossil dolphin from Kaikoura, New Zealand, helps to fill the Early Miocene gap in the history of Odontoceti. New Zealand Journal of Geology and Geophysics, 59(4):551-567. https://doi.org/10.1080/00288306.2016.1211540

Tanaka, Y. and Fordyce, R.E. 2017. Awamokoa tokarahi, a new basal dolphin in the Platanistoidea (Late Oligocene, New Zealand). Journal of Systematic Palaeontology, 15(5):365-386. https://doi.org/10.1080/14772019.2016.1202339

Yanagisawa, Y. and Akiba, F. 1998. Refined Neogene diatom biostratigraphy for the northwest Pacific around Japan, with an introduction of code numbers for selected diatom biohorizons. Journal of Geological Society of Japan, 104:395-414. https://doi.org/10.5575/ geosoc.104.395 